\title{
High Finance: Women and Staple Credit IN ENGLAND, 1353-1532
}

\author{
Richard Goddard
}

\section{Introduction: Women and Credit in Later Medieval England (and Beyond)}

This article examines women as lenders and borrowers in high-value, generally wholesale and domestic commercial credit transactions in later medieval England. As is now well known, credit was widely available throughout later medieval society and was central to all medieval business. All trade depended upon credit - the deferred part-payment for goods sold or advances for future delivery of goods. The article therefore explores the level of female participation in high-value debt transactions and it considers the important question of the sources of capital for female lenders. It also investigates the role of women in the credit market in terms of credit worthiness and reputation and finally examines the impact of global forces, such as demographic crisis, bullion famine, and severe economic recession, upon the patterns of female lending and borrowing in later medieval England. In order to answer these questions, the article analyses the debts enrolled by women in English statute staple courts between 1353 and 1532.

Richard Goddard is associate professor of medieval history at the University of Nottingham. His books include Lordship and Medieval Urbanisation: Coventry, 1043-1355 (Woodbridge, 2004); with John Langdon and Miriam Müller, eds, Survival and Discord in Medieval Society: Essays in Honour of Christopher Dyer (Turnhout, 2010); Credit and Trade in Later Medieval England (Basingstoke, 2016). He written extensively on the economic and social history of later medieval England in peer-reviewed academic journals.

Women and Credit in Pre-Industrial Europe, ed. by Elise M. Dermineur, EER 12 (Turnhout: Brepols, 2018), pp. 19-44. 
Credit in later medieval England was available from a wide variety of sources, but most commonly debt transactions were negotiated individually between merchants. The majority of credit transactions, especially those of lower value, were undertaken informally - perhaps transacted in the presence of witnesses or on the strength of a handshake - and thus only come to historians' attention when the debtors defaulted and the cases came to court. There were a large number of venues where cases of defaulted debt could be heard, including royal courts, such as Chancery or the Court of Common Pleas, and local courts such as borough and manorial courts or church courts, commonly for debt amounts of less than $40 \mathrm{~s} .{ }^{1}$ For extra security, larger debt transactions were commonly enrolled at English statute staple courts. The statute staple was a royally-sanctioned debt registration system primarily for merchants which provided a system for the efficient recovery of defaulted debts between 1353 and 1532. Debts were registered in a number of mercantile courts, sited in towns, and especially ports, of commercial importance, such as Boston, Bristol, Exeter, Hull, Newcastle, Salisbury, and Westminster. ${ }^{2}$ These are held by the National Archives under the class marks C 241 and C 152/65. ${ }^{3}$ The workings of the system are best illustrated by an example. In 1364, Joan de Fosbury (or Forstbury) of Wiltshire, the widow of a merchant called John de Fosbury, came to the statute staple Court at Salisbury and enrolled an agreement there with Nicholas Pershutte, who described himself in the document as a 'merchant of Wiltshire. ${ }^{4}$ In this recognisance, which was a binding contract between the parties, Joan de Fosbury extended $£ 200$-worth of credit to Nicholas Pershutte 'for diverse merchandise'. The agreement stated that Pershutte was required to pay this money back just over a month later. This negotiated repayment period (thirty-six days) would give enough time for Pershutte to sell the goods he had acquired on credit in Wiltshire and repay Joan de Fosbury what he owed her. Joan, the creditor, retained a copy of the agreement and in this way Pershutte formally acknowledged his debt, thereby allowing the court to take appropriate action against him should he default. ${ }^{5}$ Unfortunately Pershutte failed to repay the debt and widow de Fosbury sued him for the $£ 200$ in the Salisbury court. The documents, known as certificates, used in this study are certified extracts of the original credit agreement which were sent to

1 Goddard, Credit and Trade, pp. 44-47.

2 Goddard, Credit and Trade, pp. 4-5, 12.

3 I would like to thank Hannah Ingram for generously allowing me access to her data on the TNA C152/65 certificates.

4 The National Archives (hereafter TNA) C 241/147/118.

${ }^{5}$ Goddard, Credit and Trade, pp. 7-8. 
Chancery to enable the sheriff to imprison Pershutte, impound his lands and goods, and deliver these to de Fosbury in order to repay the outstanding amount of the debt. ${ }^{6}$ It is from these certificates, all the result of defaulted loan agreements passing through Chancery, that the debt evidence used in this article is gleaned. This process was relatively fast and provided the facilities by which England's trading community was able to borrow, often very large sums of money, relatively securely. Sums transacted in the staple courts at this period averaged at $£ 85$ and this credit was generally used to buy and sell merchandise within the English domestic economy. Some of this credit was used by English merchants redistributing imported goods throughout the kingdom. ${ }^{7}$ For example, in 1367, two Florentine merchants, Roger Thomas and Thomas Blanchard, came to the staple court at Lincoln and sold $£ 160$-worth of goods to a partnership of a merchant, William Palmer of Caistor (Lincolnshire), and Agnes, the widow of William Fitz-Simon, also of Caistor, to be repaid twenty days later. ${ }^{8}$ Although the certificates do not reveal such details, what is likely to have happened here is that the goods sold on credit by the Florentines were imports, brought in on Italian ships, and sold to the two Caistor merchants for redistribution within Lincolnshire. The business partnership of William Palmer and Agnes Fitz-Simon bought these imports on credit from the Florentines and then attempted to sell them, presumably in their home market of Caistor and its hinterland. Unfortunately, they failed to repay the Italians on time - perhaps because they were unsuccessful in selling all of the imported merchandise - and were consequently sued in the Lincoln court by the aliens, Thomas and Blanchard, only four days after the debt had fallen due. These two examples are wholly typical of the 9989 statute staple certificates from all of the English staple courts (excluding those from Yorkshire) submitted to Chancery between 1353 and 1532 in order to recover defaulted debts. ${ }^{9}$ It is these certificates submitted to Chancery that comprise the principal evidence for this study. It is estimated that these certificates of defaulted debts represent about 20 per cent of all of the staple credit transacted in the later fourteenth and fifteenth centuries. ${ }^{10}$ However, when recognisances and certificates are compared, there is no evidence to suggest that these defaulted debts

6 Goddard, Credit and Trade, pp. 9-11.

7 Goddard, Credit and Trade, pp. 85-95.

8 TNA C 241/147/54.

9 For Yorkshire, see, Kermode, 'Merchants, Overseas Trade and Urban Decline'; Kermode, 'Money and Credit in the Fifteenth Century'; Kermode, Medieval Merchants.

${ }^{10}$ Nightingale, 'Money and Credit', p. 63; Nightingale, 'Monetary Contraction and Mercantile Credit', p. 566; Goddard, Credit and Trade, pp. 15-16. 
were in any way distinctive or materially different to those debts that were paid off on time. There is no evidence, for example, that women who used the staple system defaulted more often than men. Thus, the certificates provide the best and most comprehensive source for a penetrating analysis of English trade finance, and women's engagement with that market, in the later Middle Ages. One drawback of the certificate evidence is that we remain ignorant of interest charged on loans and sales credit at this time. As is well known, in the Middle Ages, usury, or the charging of interest on loans, was forbidden by Church law, making it impossible to know whether women negotiated different interest rates than men. ${ }^{11}$

Importantly in the context of women and credit, the statute staple courts operated a system of law known as Lex Mercatoria, or 'Law Merchant'. This was an internationally acknowledged body of customs used by merchants that recognized that those engaged in commerce were often itinerant and required speedy resolution of commercial disputes, particularly those involving broken debt and credit agreements. It recognized that merchandise could be perishable and needed to be delivered, often by the merchants themselves, to distant, often overseas, markets. ${ }^{12}$ Unlike common law, this very practical system of dispute resolution seems not to have explicitly impeded or excluded women, married or otherwise, from presenting their debt plaints to staple courts. ${ }^{13}$ Indeed Matthew Stevens argues that the rules of coverture were rarely enforced even in common law courts in 'economically-oriented' pleas of debt, detinue, and account, regardless of the attempts by borough customs to regulate female traders in towns. ${ }^{14}$ Importantly therefore, women seem not to have been purposefully debarred from wholesale commercial pursuits, nor, as Teresa Phipps argues in this volume, were they denied access to the enforcement of debt laws, nor the collection of defaulted debts. ${ }^{15}$ This apparent disinterest in gender by debt courts permits a clearer view of female commercial action.

Only a limited amount of research has been undertaken on medieval women's indebtedness. This has usually been studied in conjunction with women's varied roles within the urban economy. In the majority of the studies which focus on women's work, little attention is paid to women's specific role as debtors or

11 Wood, Medieval Economic Thought, pp. 181-96.

12 Goddard, Credit and Trade, p. 6; Lex Mercatoria, ed. by Basile and others, pp. 36-67.

13 Briggs, 'Empowered or Marginalized?', pp. 13-43.

14 Stevens, 'London's Married Women and Coverture in the Court of Common Pleas', p. 120; Stevens, 'London Women, the Courts and the "Golden Age”', pp. 67-88; for borough customs enforcing coverture in trading pleas, see, Borough Customs, ed. by Bateson, pp. 227-28.

15 Teresa Phipps in this volume, pp. 73-94. 
creditors. The records of debt are utilized to study women's commercial activities rather than exploring in detail the mechanisms of credit and debt transactions or women's status within these systems. These studies told the story of English women as the mistresses of their households, belaboured with maternal duties, yet still simultaneously capable of producing all manner of industrial goods or selling small items as hucksters, and still able to come home and brew enough ale to satisfy the consumption needs of an entire parish. A significant proportion of these working women appear to have been engaged in marginal occupations, with domestic service being a perennial characteristic of female employment. ${ }^{16}$ In the course of their commercial activities, these women regularly lent and borrowed money and extended sales credit to customers or purchased goods on credit. When these types of low-level, commonly informal, commercial credit transactions went wrong, the disputes were settled in borough and manorial courts. ${ }^{17}$ In these courts, women transacted debts less frequently than men. In Exeter's borough court for example, women comprised only a small proportion (approximately 10 per cent) of debt litigants. The amounts transacted, particularly by women acting on their own, were far lower, often less than half, than the mean value of men's debts. ${ }^{18}$ Teresa Phipps found that whilst debt pleas involving women in the later fourteenth century were, on average, only slightly smaller in value (53d.) when compared to men's debts (68d.), women only counted for between 15 and 17 per cent of all debt litigation in the borough court of Nottingham, with a similar proportion of female debt litigants being present in Winchester (12-16 per cent) and with a lower participation rate in Chester ( 7 per cent) at the same time. ${ }^{19}$ Chris Briggs similarly argued that women, both married and single, in rural communities had little direct access to credit and that this limited their commercial activities. ${ }^{20}$

However, the lower-value debt transactions pursued in borough courts generally used to fund local retail commerce - were intrinsically different to the high-value credit transactions enrolled in staple courts. The mean debt amounts, for all litigants including both men and women, pleaded for in the borough courts

16 Inter alia, Lacey, 'Women and Work in Fourteenth and Fifteenth-Century London', pp. 24-82; Kowaleski, 'Women's Work in a Market Town', pp. 145-64; Goldberg, Women, Work and Life-Cycle in a Medieval Economy.

17 Phipps, 'Urban Women and Local Justice', p. 170.

18 Kowaleski, 'Women's Work in a Market Town', pp. 149-51.

19 Phipps, 'Gendered Justice?', p. 81; Phipps, 'Urban Women and Local Justice', pp. 136, 150 .

${ }^{20}$ Briggs, 'Empowered or Marginalized?', pp. 13-43. 
of Exeter, Colchester (Essex), Nottingham, Ramsey (Cambridgeshire) and Thornbury (Gloucestershire) ranged between 4s. and 11s. $7 \mathrm{~d}$. in the later Middle Ages. ${ }^{21}$ As cited above, the mean value of debts registered at the English staple courts was $£ 85$ in the same period. Positioned between modest debt pleas brought to borough and manorial courts and the 'high finance' of the staple transactions was the Court of Common Pleas, studied by Matthew Stevens. ${ }^{22}$ As in manorial and borough courts, debt pleas brought to this Westminster court were generally informal agreements (those unsupported by writs or recognisances). The proportion of married women litigants involved in these economically-orientated pleas of debt, detinue, and account was roughly 16 per cent in the Common Pleas and the average debt value for female litigants was $£ 116 \mathrm{~s} .8 \mathrm{~d} .{ }^{23}$ Whilst there are some passing similarities between the experiences of women using the staple courts for their debt transactions and those using borough or Common Pleas courts, a more analogous set of circumstances is seen in the records of credit agreements used in international or wholesale trade. Shennan Hutton's work on married women in Ghent in the mid-fourteenth century reveals that 24 per cent of the credit agreements listed in Ghent's aldermen's registers included at least one woman acting in her own name. ${ }^{24}$ These transactions were used to fund trading ventures and as investment capital rather than being used for domestic purchases. As in the staple courts, Hutton argues that the aldermen did little to obstruct women, married or otherwise, in their commercial debt transactions, but rather enforced these debt contracts with what appears to have been relative even-handedness. In terms of debt amounts, women and men lent and borrowed small and medium-sized amounts in equal measure, but far fewer women transacted the largest sums. Many of these women came from the families of prominent business and political leaders of the city. ${ }^{25}$ Wendy Childs's work on English mercantile credit used to purchase alien imports in the mid-fifteenth century (the debt amounts fell commonly between $£ 2$ and $£ 200$ ) demonstrates that married women, in partnership with their husbands, and particularly widows, extended only small sums to German merchants. This, when compared to the transactions of male merchants, marked these female

${ }^{21}$ Goddard, Credit and Trade, p. 149.

22 Stevens, 'London's Married Women', p. 117.

23 Stevens, 'London's Married Women', pp. 120, 130.

${ }^{24}$ Hutton, Women and Economic Activities, pp. 81-101.

${ }_{25}$ Hutton, Women and Economic Activities, pp. 82-90, 99; Hutton, 'Property, Family and Partnership', p. 116. 
merchants out as peripheral or occasional dealers in foreign imports at that time. ${ }^{26}$ These merchants did not use the staple system to enrol these debts but the international commercial context and size of these credit agreements are comparable to those brought before the staple courts and offer some scope for comparison. This article therefore seeks to broaden the study of women and debt by moving beyond the study of women and debt at the lowest level of the economy - in borough and manorial courts - to examine, for the first time, high-value debt transactions undertaken at English staple courts in the later Middle Ages.

\section{Later Medieval Women and Staple Debt}

In the broadest possible terms, it can be stated that 379 of the 9989 certificates studied here (3.79 per cent) between 1353 and 1532 feature women as active participants in the staple credit process either as lenders or borrowers. The vast majority of these agreements are likely to have been commercial in nature. ${ }^{27} \mathrm{~A}$ similar proportion (2.6 per cent) is found in the recognisances enrolled at Coventry's statute merchant court. ${ }^{28}$ Recognisances were the first part of the debt enrolment process and those from Coventry are rare survivals of all of the debt agreements enrolled at that court between 1392-1456 and 1521-1535, rather than just those certificates that were part of the defaulted debt recovery process which comprise the principal evidence used in this survey. The inclusion of the Coventry recognisances allows for a more exhaustive and precise picture of male and female lending and borrowing at this time to be drawn. The fact that the proportion of female users in both sets of records falls at about 3 per cent suggests that women were less frequent participants in wholesale, high-value debt transactions than they were in the lower-value, probably retail, credit disputes found in borough courts (7-17 per cent) or the Court of Common Pleas (c. 16 per cent). This is all the more compelling because borough or manorial courts which, as customary courts, adopted many principles of common law, the Law Merchant which operated in staple courts, as discussed above, did not seem to explicitly debar married women. Why did women participate only peripherally in English high-value trade finance in this period?

\footnotetext{
${ }^{26}$ Childs, “'To oure losse and hindraunce”,'p. 85. This work deals only in passing with female debt.

27 Goddard, Credit and Trade, pp. 21-28.

28 The Statute Merchant Roll of Coventry 1392-1416, ed. by Beardwood (Dugdale Society Publications, 17, 1939); Coventry Record Office (hereafter CRO) BA/E/C/7/1-35.
} 
The answers to this question tell us much about women's access to high finance, business opportunities, and capital within a patriarchal society.

The data from the staple certificates suggest that it was rare for women, other than widows, to transact staple debts by themselves. There is a small group of fourteen women who, unlike the majority of women using the staple, are not described in terms of their status as wife, widow, mother, or daughter who transacted credit deals on their own. Women such as Isabel de Claregge, who extended 92 marks to a Suffolk merchant named John Prycke in 1362; Joan Whaplode, who borrowed $£ 20$ from a London mercer in 1395, and Alice French of Oxford, who extended $£ 40$ worth of credit to a local customer, John Cheyne of Chenies (Esnamstedecheyne) in $1411 .{ }^{29}$ These women could have been widows, although not described as such; they could have been single, as the 'single-woman' descriptor was not used in this context, or they could have been wives operating on their own. It is known, for instance, that Joan Whaplode's husband, John, was alive three years after Joan enrolled the debt agreement with the London mercer, Robert Sherwynd, at the Westminster staple. ${ }^{30}$ This means that Joan was married at the time she transacted the deal. John is not cited at any point in the debt agreement. Even those who described themselves with reference to their living husbands could act alone, unlike, in theory at least, in those courts that utilized the conventions of common law. In 1518, Angela Johns enrolled a debt agreement at Westminster by which she lent $£ 40$ to a syndicate of three (one of whom was a woman) business people. Johns described herself in this certificate as 'wife of William Johns, mercer of London, recently wife of Thomas Burgogne'. ${ }^{31}$ Despite being a newly remarried widow, she entered into this debt agreement without her new husband.

However, women who were not widows rarely acted alone. It was more common for women to act in partnership with men. Whole families could act together. In 1396, Henry Duraunt, citizen and barber of London, his wife Alice, and John, their son, transacted a deal together in which they borrowed $£ 40$ from a London tawer. ${ }^{32}$ As discussed below, mothers (and occasionally stepmothers) lent and borrowed with their sons. In 1389, the 'merchant' Isabel Torinton of Bristol borrowed $£ 300$ from a Bristol merchant in partnership with her son, John, who was also described in the certificate as a 'merchant of Somerset'; in the mid-fifteenth

29 TNA C 241/188/17; C 241/143/69; C 241/209/23.

30 TNA C 143/427/12; C 146/435; John Whaplode died in 1400; see Corporation of London Record Office, CLA/007/EM/02/I/004; CLA/007/EM/04/002/259/291.

31 TNA C 152/65/2/750.

32 TNA C 241/188/47. A tawer is a person who prepares white leather. 
century, Joan Langton extended credit in partnership with her son, John, to a partnership of two London merchants. ${ }^{33}$ These children could not have been minors, so this suggests that these women played an important role in these ventures, possibly injecting capital into their businesses.

Table 1.1. Widows and wives in staple certificates with percentages $(\mathrm{N}=313)$. Source: TNA C 241 and C 152/65.

\begin{tabular}{lcccc}
\hline Descriptor & Debtors & Creditors & Total & $\begin{array}{c}\text { Percentage of all female certificates } \\
(\mathbf{3 7 9 )}\end{array}$ \\
\hline Widow & 86 & 107 & 193 & 50.9 \\
\hline Wife & 66 & 54 & 120 & 31.7 \\
\hline
\end{tabular}

Wives and widows comprise over 80 per cent of the female debts. ${ }^{34}$ Those describing themselves as 'wife (uxor)' feature strongly amongst the female users of the statute staple, occurring in over one third of these certificates (see Table 1.1). In most of these cases, and unlike the Joan Whaplode and Angela Johns examples above, the transactions were enacted jointly with their husbands. For example, in 1406 John Cole, a wine merchant from London, and Juliana his wife received credit from a London grocer called Thomas Mayneld, and in 1360 John de Newborough, and his wife Joan, described in the certificate as 'merchants of Dorset', extended $£ 100$-worth of credit 'for divers merchandise' to a fellow Dorset merchant called William de Stupelton. ${ }^{35}$ In these cases, as Table 1.1 shows, husbands and wives working together borrowed slightly more often than they lent. The fact that wives and husbands enrolling debts together - effectively creating a legally binding business partnership — were the second most common type of certificate involving women, supports the idea that medieval business was indeed a household-based affair, with all the opportunities for capital acquisition that marriage could bring. Indeed, it is likely that this underrepresents the proportion of women directly involved in high-value debt transactions at this time as wives may have been unnamed or silent partners in many of the remaining 9632 staple agreements that cited only men. Importantly in this regard, it was much more

${ }^{33}$ TNA C 241/143/69; C 241/190/27; C 241/248/6. Other examples include, C 241/249/42; C 241/156/7.

${ }^{34}$ The proportion of women using the English staple courts did change over time. This is discussed in more detail below.

35 TNA C 241/204/29; C 241/145/84; for similar examples from the Coventry recognisances, see The Statute Merchant Roll of Coventry, ed. by Beardwood, pp. 8, 58. 
common for women to work with their husbands than to become business partners with men to whom they were (apparently) unrelated. Alice Ive, of Tenterden in Kent, did extend credit with another local man to whom she does not appear to be related, John Petilysden of Rolvenden (4.5 km from Tenterden) in 1416, as did Cecilia Herberfield, who, with two other Oxford men, Roger Folkes and Robert atte Wood, extended 200 marks-worth of credit — possibly for goods supplied — to a Berkshire gentleman in $1441 .{ }^{36}$ The Coventry recognisances tell a similar story. There were occasions when women, commonly the widows of important and wealthy local merchants, extended credit in partnership with other important Coventry merchants, as did Alice de Dodenhale. ${ }^{37}$ As discussed below, it is likely that these widows possessed sufficient capital reserves to allow them to make a meaningful financial contribution when extending sales credit. But instances like these were relatively rare, suggesting that it was more conventional, within a patriarchal society like this one, to conduct business in partnership with a man with whom a woman had a spousal link.

\section{The Quest for Capital: A Widow's Assets}

Central to the discussion of women, credit, and trade is the question of access to capital. Managing, and particularly funding, a highly capitalized international trading venture, of the kind undertaken by Ghent's female merchants or those English women dealing in German imports required significant amounts of capital. However, Judith Bennett famously argued that women were disadvantaged and in a subordinate position in terms of capital acquisition. Single-women's limited access to capital in the later Middle Ages resulted in their virtual exclusion from the capitalintensive beer-brewing industry. Those who responded best to these new opportunities were those - generally men - who commanded the capital resources to invest in suitable premises, superior equipment, and waged labour. 'These expanding capital demands placed women at a severe disadvantage, a disadvantage that came to be seen most clearly among women who lacked ready access to the greater economic resources of men, that is single women and widows. ${ }^{38}$ Women's use

36 TNA C 241/210/25; C 241/237/16. For other examples, see, C 241/202/58; C 241/190/72; C 241/275/280.

37 The Statute Merchant Roll of Coventry, ed. by Beardwood, p. 53. Henry de Dodenhale was a heavy user of the statute staple system and mayor of Coventry. For Dodenhale's debts, see, TNA C 241/140/134; C 241/140/149; C 241/140/89; C 241/153/22.

38 Bennett, Ale, Beer, and Brewsters, pp. 52-55, 88-92, 154, 150. 
of, and participation in, the staple credit process needs therefore to be considered within this more demanding and onerous context of later medieval female merchants' access to capital.

Any comparison between male and female debt amounts is unrevealing for the simple reason that, as discussed above, it was less common for women to enter into staple debt agreements by themselves. Thus the mean debt amounts of certificates involving women (staple certificates: $£ 91$; Coventry recognisances: $£ 87$ ) are strikingly similar to the mean values of the sample as a whole (staple certificates: $£ 85$; Coventry recognisances: $£ 69$ ). The reason for this is that most debt transactions involving women, in common with those at the Court of Common Pleas studied by Stevens, were transacted jointly with men, often the woman's husband. ${ }^{39}$ When women did enrol debt transactions singly, most commonly as widows, there is no evidence that the mean value of these debts (£85) differed greatly those of the sample as a whole $(£ 85)$, nor were they substantially lower than when widows transacted debts in partnership with men (£98). By comparison, in Exeter's borough court, as in the staple, wives often appeared with their husbands in debt suits, with debt amounts being similar in scale to men's. ${ }^{40}$ Exeter's borough court rolls recorded disputes over low-value debts (generally 14s. or less) that funded the city's local trade; the staple funded high-value wholesale domestic trade where the average debt value $(£ 85)$ was over eighty times larger than those at recorded at Exeter. One conclusion that might be posited here is that as debt transactions increased in value, thus requiring larger injections of capital — such as those enrolled in the staple courts - the proportion of women participating in these commercial ventures fell $-c .3$ per cent at the staple compared to 7-17 per cent found in borough courts and the $c .16$ per cent female participation at the Court of Common Pleas. To put it another way, women were less active in 'high finance' - such as that represented by the staple - as this required control over significant resources or assets and possibly goes some way to explain the low c. 3 per cent participation rate of women in staple credit agreements.

Capital was available for women from a number of sources. An important source of capital was land. Using staple credit enabled users to convert a fixed asset like land into working capital. One woman who seems to have used her estates in this way was Coventry's Elizabeth de Clynton. In 1410 and 1414 she lent very large

39 These exclude unrepresentatively large outliers in both sets of data. Goddard, Credit and Trade, p. 28; Stevens, 'London's Married Women', pp. 120, 130; Judith Bennett also argued that women gained access to capital through their husbands, see, Bennett, Ale, Beer, and Brewsters, pp. 88-92.

40 Kowaleski, 'Women's Work in a Market Town', pp. 149-51. 
sums (1000 marks and $£ 400)$ to two different syndicates of Warwickshire businessmen. ${ }^{41}$ Neither loan was repaid and she subsequently sued these syndicates through the courts. In the recognisance, she describes herself as 'Elizabeth, Lady of Clynton'. ${ }^{42}$ John de Clinton (or Clynton), her third husband, held estates in Warwickshire (including the ancestral home of Maxstoke), Essex, Lincolnshire, Yorkshire and Norfolk (some of the Norfolk estates were held jointly with his wife). ${ }^{43} \mathrm{He}$ had died in 1389, leaving Elizabeth in control of a valuable body of landed assets. The assumption here is that she deployed some of these landed assets - thereby converting them into a more liquid configuration - in these transactions enrolled at Coventry's debt court. ${ }^{44}$ As usual, the recognisances do not indicate what the money was to be used for, but it is not impossible that this was some form of venture capital. The certificates do not reveal Elizabeth de Clynton's motives or incentives, financial or otherwise, for being a party to these agreements. As stated above, we have no information about interest rates paid at this time and so any pecuniary benefits to her remain hidden from us. However, landed female creditors were not uncommon in the staple certificates sent to Chancery. Knights' widows, such as Lady Alice de Nevyle and Lady Joan Felton, lent to individuals using the staple. ${ }^{45}$ However, it was more common for the wives of knights, such as the prolific Lady Alice Gyffard (with five certificates to five separate individuals, totalling £520), to transact debts jointly with their husbands. ${ }^{46}$ Access to sufficient capital must therefore have played a key, self-selecting, role in financing high-value trade.

A second source of capital was dowries. Table 1.1 clearly demonstrates that widows, both singly and jointly with male business partners, were an important constituent of women's use of the staple. As is well known widows are more 'visible' than other women in medieval court records, not least because they were no longer

${ }^{41}$ The Statute Merchant Roll of Coventry, ed. by Beardwood, pp. 60-61, 67.

${ }_{42}$ The Statute Merchant Roll of Coventry, ed. by Beardwood , pp. 67-68; 70-71; TNA C 241/218/13.

43 The Statute Merchant Roll of Coventry, ed. by Beardwood, pp. 70-71; 'Inquisitions Post Mortem, Richard II, File 54', ed. by Dawes and others, pp. 249-263. British History Online <www.british-history.ac.uk/inquis-post-mortem/vol. 16/> [accessed 8 May 2016].

${ }_{44}$ Postan, 'Credit in Medieval Trade', p. 248; Kermode, 'Money and Credit in the Fifteenth Century', p. 488.

45 TNA C 241/165/14; C 241/194/41.

46 TNA C 241/152/36; C 241/153/140; C 241/155/52; C 241/155/53; C 241/155/75; three other transactions she undertook alone, several years later, presumably as a widow, $\mathrm{C}$ 241/158/106; C 241/170/23; C 241/156/31. 
hampered by the rules of coverture. ${ }^{47}$ When discussing London widows, Barron shows that they were entitled, indeed expected, to continue or maintain their late husband's business, or indeed establish new business enterprises on their own. They had rights to occupy the family house, workplace, or shop, and a share in other lands and tenements belonging to the husband, and to a third (or half, depending on children) of the husband's goods and chattels. In mercantile households, where assets were often in the form of movable goods, this was an important source of capital. In London, these movable goods were the widow's to exploit as she wished. London widows were also given the opportunity to join the economic and social (but not political) life of guilds and merchant companies. ${ }^{48}$ These factors may help to explain the fact that widows were the largest group of women to transact debt agreements individually using the staple. Just over half ( 55.8 per cent) of the widows who used the staple did so alone. Many, such as Joan Leverych ( $£ 40$ in 1399) and Elizabeth Hawkins (200 marks in 1529) extended credit singly to merchants. ${ }^{49}$ For example, Elizabeth Yarford, a London widow, gave $£ 3213$ s. $4 \mathrm{~d}$.-worth of credit in 1527 to a mercer and merchant of the Calais staple, John Pais, presumably, judging from the debtor's occupation, in some form of mercantile transaction. ${ }^{50}$ However, the remaining (44.2 per cent) staple widows enrolled their debts with other men - sometimes their sons - perhaps in so doing supplying or increasing the amount of capital brought to the venture. For example, in two separate transactions in 1402 and 1407 , the London widow, Joan Wight, extended a total of $£ 36$-worth of credit to a London tailor, Thomas Awdele (or Audley). In both transactions she acted in partnership with a London vintner called Alexander Sprot. Joan Wright's late husband, like the debtor, had been a tailor, suggesting perhaps a continuation of the family business. ${ }^{51}$ In terms of the availability of specifically mercantile capital for staple widows, seventeen of these women's late husbands ( 8.8 per cent) were cited in the certificates as being members of important London livery companies: the Mercers, Haberdashers, Vintners, Drapers, Fishmongers, Grocers, and Leathersellers. ${ }^{52}$ Their widows' use of the staple suggests that these men, all of whom would

47 Barron, 'Introduction: The Widow's World in Later Medieval London', p. xiii.

48 Barron, 'Introduction: The Widow's World in Later Medieval London', pp. xvii-xxii, xxviii.

49 TNA C 241/192/79; C 241/281/133.

50 TNA C 241/282/94.

51 TNA C 241/198/77; C 241/202/58.

52 See, inter alia, TNA C 241/182/71; C 241/212/9; C 241/272/15; C 241/186/81; C 241/209/63; C 241/212/13; C 241/266/43. 
have been engaged in wholesale mercantile activities, not only bequeathed a viable business and the knowledge and connections that came with it, but also made over sufficient assets or movable goods to allow their widows to effectively continue their mercantile pursuits. Indeed, in general, those widows who contracted the largest debts were either widows of members of the gentry, such as Anne Tirell, widow of an esquire, who in partnership with another esquire, John Bowet, lent 800 marks in 1432, or the widows of merchants, such as Joan de Fosbury, cited above, whose husband, John, had been a Wiltshire merchant; or Agnes Spelly, who was the widow of a Bristol merchant called Ellis and who lent $£ 200$ to another Bristol merchant in $1391 . .^{53}$ Thus the inheritance of viable assets must have played a decisive role in female participation in staple debt agreements. Indeed, access to capital and its use to fund trade at staple courts might have increased a woman's status and reputation and integrated her into powerful financial networks. This goes some way to explain the high proportion of widows engaged in staple high finance seen in Table 1.1.

\section{Women as Guarantors? The Baroness and the Yeoman}

In 1472, Simon Ludbrook, a London draper and Henry Ashbourne, another Londoner, extended $£ 12$-worth of credit to John Morteyne, a London tailor, and Katherine Morteyne, probably his mother. ${ }^{54}$ This is likely to have been credit for raw materials, probably cloth to be used in the tailor's workshop - interestingly run by a mother and son partnership - rather than the more usual large-scale transaction for merchandise. It is tempting to ponder whether Katherine Morteyne was acting in this agreement as a respected and creditworthy guarantor for her inexperienced son or a relative who perhaps lacked a pristine credit record in the market place. If we read these join ventures between mothers and sons or widows and other business partners in this way, it slightly reorients our understanding of women and high finance in the late Middle Ages. Might certain women - creditworthy and reputable women with viable assets or capital - have been seen as more trustworthy and reliable than, at the

53 TNA C 241/225/4; C 241/147/118; C 241/183/3. The gentry in this period regularly engaged in commercial activities, see, Goddard, Credit and Trade, pp. 24-28. Widows of gentry comprise 55.1 per cent ( 48 female certificates) of the female certificates; widows of merchants and associated wholesale traders, comprise 44.8 per cent (39 female certificates). However, accurate allocation of a late husband's status or occupation is only possible in 44.8 per cent ( 87 female certificates) of these certificates.

54 TNA C 241/254/120. For a similar example, see, C 241/175/102. 
very least, disreputable, men? Might they have been cited as partners in these transactions, not because they were actively involved in trade, but rather because they were providing security for less reputable or less experienced men? As is well known, credit relations in the face-to-face world of pre-industrial business were dependent upon social relations, trust, friendship, and networks, making a credit partnership with a reputable widow a powerful stratagem for furthering a trading career. ${ }^{55}$ Within the staple evidence there are a number of occasions where a son is extended credit in partnership with his mother but then goes on to make deals on his own account. In 1389, Hugh Middleton, an esquire from Greenwich (Kent), borrowed $£ 54$ 16s. from Londoner, Richard Blomvyle, a member of the Stockfishmongers' guild, probably here purchasing goods on credit for his household. ${ }^{56}$ In this deal he was in partnership with a relation, probably his widowed mother, Elizabeth Middleton. Conjecturally the widow's creditworthy reputation, along with her (assumed) knowledge of her late husband's business, gave Hugh Middleton financial standing, placating the worries of the experienced London merchant and allowing the transaction to go ahead. Indeed, five months later, before the previous debt was due, Hugh Middleton and another esquire were extended credit (for $£ 516$ s. 8 d.) again by another London merchant, the grocer, Robert Chichele. ${ }^{57}$ But this time, Hugh did not feel it necessary to include Elizabeth in the transaction. Might these events be read as an inexperienced or unknown debtor having found his feet in the market with his mother's help going on to transact business on his own? Other similar examples can be found in the staple evidence. In 1474, Thomas Robyns of the Fishmongers' Company of London was extended $£ 12$-worth of credit by another London Fishmonger. ${ }^{58}$ Once again the certificate cites Alice Robyns, of Stratford le Bow (Middlesex), widow and again probably his mother, as the co-debtor. Four years later, Thomas Robyns was conducting business alone, his mother having supported his early forays into business. ${ }^{59}$ As men could trade and make contracts on their own with no legal impediments, these connections between women and men might well indicate that wives and mothers were playing active roles in these transactions - as business partners, experienced advisors, or guarantors - rather than merely passively underwriting a debt with their reputation and resources. If reputable women, particularly those with viable

55 Muldrew, The Economy of Obligation, p. 2; Howell, Commerce Before Capitalism in Europe, 1300-1600, p. 25.

56 TNA C $241 / 189 / 31$.

57 TNA C $241 / 189 / 10$.

58 TNA C 241/258/117; for a similar example, see, C 241/270/12.

59 TNA C 241/258/88. 
assets, were considered a safe debt risk then other, non-familial examples should be locatable in the staple evidence. In 1465, an aptly-named yeoman from Hambleden (Buckinghamshire) called Robert Plough sought $£ 44$ 16s. 1d.-worth of credit from a London mercer, Thomas Lymnor. ${ }^{60}$ Yeomen were usually freehold peasant tenants or demesne farmers, often with extensive landholdings, so this would have constituted a very large and expensive transaction for him. In order to obtain this credit, the Buckinghamshire yeoman, who had probably never bought from the London mercer before, required extra security in order to more easily facilitate this transaction. However, Robert Plough had powerful friends. For this transaction he turned to Elizabeth Scrope (or Scroop), from Bolton (Yorkshire). Elizabeth was the widow of Henry, fourth Baron Scrope, a major Yorkshire landholder, soldier, and important royal servant and so she is likely to have exercised considerable influence. ${ }^{61} \mathrm{We}$ will never know how the yeoman and the baroness knew each other, probably meeting in Westminster where the debt was enrolled, but their partnership resulted in the credit being extended by the London mercer. Ultimately, the debt was not repaid on time and Robert Plough and Elizabeth Scrope were sued in the staple court. Therefore, there was always a risk associated with debt partnerships of this scale.

Seemingly, a woman's unshakable reputation could be used to smooth the way for a debt transaction even if the woman herself was dead. In 1528, George Tomson, citizen and barber of London, sought to borrow $£ 100$ from London mercer, Michael Dormer. ${ }^{62}$ The certificate, rather unusually, sees him reeling off the names of his creditworthy relations in order to demonstrate that he was good for the debt. He points out that he is the stepbrother (although he describes him just as 'brother') and heir of William Magelyn, gentleman; both George Tomson and his stepbrother were sons and heirs of the now deceased widow, Margaret Tomson. He stresses his late, oft-married mother's social position, wealth, and status. The certificate describes her as the daughter and heiress of Thomas Upton, gentleman, now also deceased, then the wife of Richard Tomson, a Lincolnshire yeoman (George's father), now also deceased. Before her marriage to Tomson Margaret had been married to Thomas Magelyn, gentleman (William Magelyn's father), again also deceased. Whilst George may well have been fond of his mother and proud of her lineage, his emphasis on the fact that she had been the beneficiary of a number

60 TNA C 241/254/19.

${ }^{61}$ P. W. Hammond, 'Scrope, John, Fifth Baron Scrope of Bolton (1437/8-1498)', Oxford Dictionary of National Biography, Oxford University Press, 2004 <www.oxforddnb.com/view/ article/24961> [accessed 10 June 2016].

62 TNA C 241/279/119. 
of advantageous dowries, to which he now had access, allows him to suggest to the creditor that the resources required to repay the debt on time were readily available. As it happened, he failed to do so and was sued by Michael Dormer just four days after the debt was defaulted.

If, as suggested above, reputable women might be able to facilitate credit transactions then it might have been advantageous for merchants with poor credit histories to enter into business partnerships with trustworthy women of good repute. In 1363, the mercer John de Wisbech, of London, sought to borrow $£ 40$ from Adam Fraunceys, a wealthy, influential and powerful London mercer. ${ }^{63} \mathrm{We}$ are unaware of the circumstances of the transaction and the stipulations of the creditor, but John de Wisbech entered into it in partnership with his mother, Alice. It is possible that the experienced creditor, Fraunceys, was aware of Wisbech's credit record. Two years earlier, in 1361 , Wisbech had failed to repay a $£ 30$ debt to a Suffolk clerk, thus possibly making Fraunceys more circumspect about extending credit to Wisbech this time without his mother being named in the certificate and acting as a guarantor. ${ }^{64}$ Examples like these are not common and we do not know the details or circumstances of these transactions, but it is possible that in some cases women, and especially widows well provided with assets, enhanced debtors' social capital and reputation when negotiating credit agreements in staple courts. ${ }^{65}$ Whilst female guarantors are difficult to identify with any certainty within the medieval data, it is an area worthy of further investigation.

\section{'Golden Ages'? A Chronology of Women's Engagement with Staple Debt}

The volume of staple debt evidence available allows some tentative conclusions to be drawn concerning the chronology of female participation in high-value debt transactions over the period 1353-1532. If the number of certificates sent to Chancery are divided decennially into (roughly) fifty-year blocks, then interesting patterns can be discerned. Figure 1.1 displays these data.

The patterns of borrowing and lending involving women outlined in Figure 1.1 suggest that the greatest number of women participated in staple credit transac-

${ }^{63}$ O'Conner, 'Finance, Diplomacy and Politics'.

64 TNA C 241/143/83.

${ }^{65}$ Another possible example is James More; see TNA C 241/275/246; C 241/275/153. 


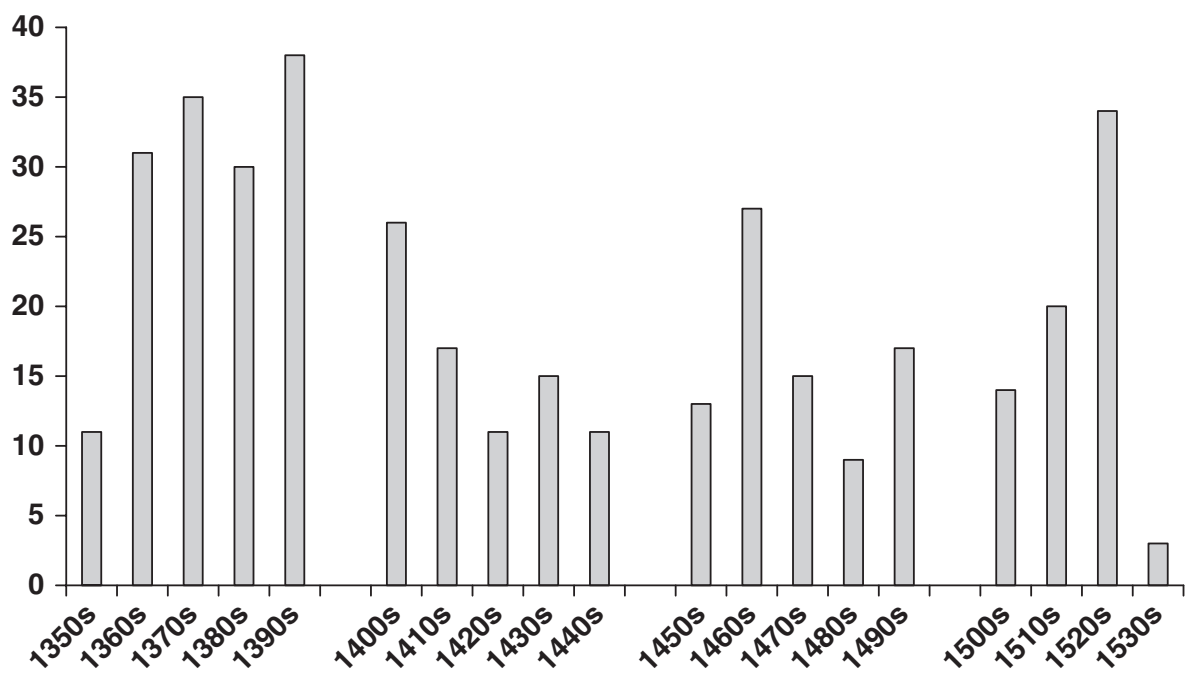

Figure 1.1. Decennial trends in staple debt registration involving women, 1353-1532 (N =377). Source: TNA C 241 and C 152/65.

tions in the decades following the Black Death with particular growth in numbers of female certificates between the 1370s and the 1390s. The 1390s represent the high point of female participation in staple transactions with women contributing to thirty-eight certificates in that decade. One possible explanation for this apogee in female lending and borrowing using the staple is the so-called 'Golden Age' hypothesis, wherein, as a result of high mortality and depopulation resulting from repeated outbreaks of plague, economic opportunities for women may have increased. ${ }^{66}$ This hypothesis has not always been greeted with enthusiasm and indeed, as discussed below, a simpler explanation for this late fourteenth-century peak in female debt traffic, and the patterns that follow it, can be advanced. The number of female certificates drop significantly in the next fifty-year period of the early fifteenth century with just over half the number of certificates involving women being sent to Chancery at that time. The real crisis in female certificates starts in the 1410s and continues until the end of the 1440s (see Figure 1.1). The number of female certificates in the next fifty-year period of the later fifteenth

${ }^{66}$ For a discussion of the 'Golden Age' hypothesis, see Barron, 'The "Golden Age" of Women in Medieval London', pp. 35-58; Hanawalt, 'Golden Ages for the History of Medieval English Women', pp. 1-24; Stevens, 'London Women, the Courts and the "Golden Age”', pp. 67-88. 
century remains at a low ebb, but there is some evidence of a hesitant recovery. The 1460s represent a particular high point here with twenty-seven Chancery certificates involving women being enrolled in that decade. Some historians have argued that the rising population of the early sixteenth century might have reduced economic opportunities for women, as seen, for example, in increasingly restrictive craft regulations for women. ${ }^{67}$ However, this period was one of growth in the number of female certificates being enrolled at staple courts in England. The number of female certificates rises continuously through the first three decades of the sixteenth century, with particular growth being shown in the 1520 s with thirty-four female certificates, a number that almost recaptures the glories of the later fourteenth century.

This pattern of female staple debt enrolment follows, almost exactly, the trends exhibited by the complete set of nearly 10,000 surviving certificates. This pattern is represented in the decennial data described in Figure 1.2.

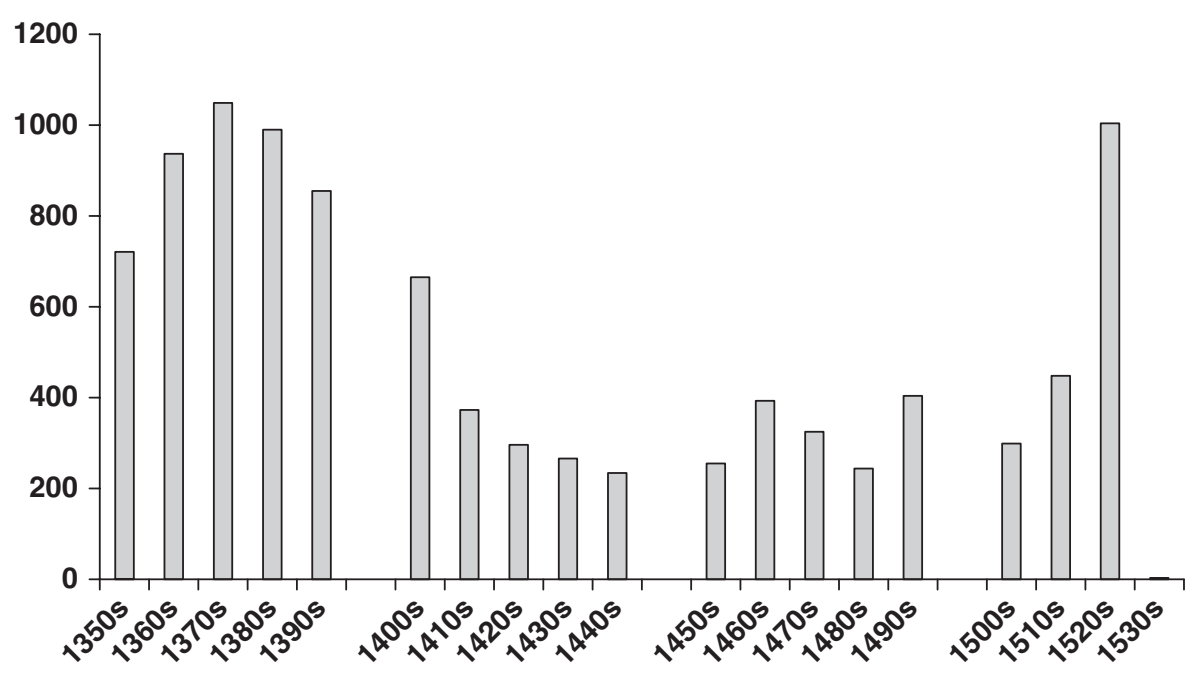

Figure 1.2. Decennial trends in staple debt registration, 1353-1532 (N = 9,841). Source: TNA C 241 and C 152/65. ${ }^{68}$

${ }^{67}$ Herlihy, Opera Muliebria, pp. 168, 190; Barron, 'The “Golden Age"', pp. 48-49; Barron, 'Introduction: The Widow's World in Later Medieval London”, p. xxxiv.

68 One hundred and forty-eight of the certificates do not have recoverable transactions dates. For a fuller discussion of these figures, see, Goddard, Credit and Trade, pp. 97-129. 
A comparison of Figures 1.1 and 1.2 starkly reveals the minimal (c. 3 per cent) participation of women in staple debt agreements. From this comparison it can be seen that the general chronology of staple debt enrolment for men and women similarly peaks in the later fourteenth century, drops by more than half in the following fifty-year period, falls slightly in the later fifteenth century and starts its early sixteenth-century climb during the first thirty years of that century. This chronology fits well with our understanding of a confident post-plague business environment and economic resilience in the later fourteenth century ${ }^{69}$ followed by a severe recession in the early fifteenth century with particular economic problems being felt between the 1440s and 1470s. ${ }^{70}$ The staple debt evidence places the gravest period of recession in the $1420 \mathrm{~s}$ and $1430 \mathrm{~s}$, to be followed by what might be interpreted as a faltering recovery with large spikes in debt enrolments at staple courts in the late 1450s, early 1470s, and 1490s (albeit with each being followed by significant falls). The economic recovery of the following period seen in the debt evidence is similarly well attested in the historiography of the early sixteenth century. It was a period that marked the end of the agrarian crisis in England and the start of a recovery in both population and life expectancy in the kingdom. ${ }^{71}$ Thus the most prosaic explanation of trends in female debt registration, in which golden ages play no part, is simply that, for the most part, female debt enrolment closely follows the chronology of economic growth and decline delineated throughout the sample as a whole. This is unsurprising as debt agreements involving women make up a very small part of this sample and, generally, when women became involved in staple debt registration, they tended to do so, as seen above, in partnership with men. What might this tell us about the gendering of women's economic involvement in high finance in the later Middle Ages? It does not seem to suggest a particularly gendered chronology. It could be argued that, despite the demographic collapse in the later fourteenth and fifteenth centuries, women did not fill the void but rather were subject to the same economic pressures of growth and decline experienced by male merchants in the economy as a whole.

69 Bridbury, Economic Growth, pp. 25-27, 35-36; Hatcher, Plague, Population and the English Economy, 1348-1530, pp. 31-35; Britnell, The Commercialisation of English Society, 10001500, pp. 194-96.

70 Britnell, Britain and Ireland, 1050-1530, pp. 327, 329, 330, 332; Goddard, Credit and Trade, pp. 109-119; Hatcher, 'The Great Slump', pp. 237-72.

71 See, inter alia, Brown, 'Surviving the Mid-Fifteenth-Century Recession', pp. 209-31; Dyer, Lords and Peasants in a Changing Society, pp. 165-85; Hatcher and others, 'Monastic Mortality', pp. 667-87. 


\section{Conclusions: Beatrice Lavender and the 3 per cent Benchmark}

Women represented only a minority of users of English staple debt — rarely more than 3 per cent - in the later Middle Ages. Yet there appears to have been no particular injunction against women using this process of debt enrolment and recovery, albeit within a pervasive patriarchal society. How should this low participation rate, lower than that of women suing for debt in borough courts or the Court of Common Pleas, be explained? The staple was predominantly used to fund English domestic wholesale trade and the marketing of imported goods within the kingdom. However, the capital requirements of investing, even in domestic trading ventures, required considerable resources in order to operate effectively within this competitive market. Women's low participation in high finance through the staple would seem to confirm that they were disadvantaged in terms of capital acquisition. At the same time, it is important to remember that this was also true for the majority of men. Most male English merchants were rarely involved in high finance on this scale. However, some women did become involved in lending and borrowing using the staple. The capital they employed could come from landed estates, but often women gained access to a husband's capital, commonly through marriage. Many of these women were the wives, widows, or daughters of important merchants, generally wealthy ruling members of mercantile urban oligarchies. One possible reading of the staple evidence suggests that some highly capitalized and creditworthy female debtors may have been employed as guarantors - rather than being actively engaged in wholesale trade - when entering into credit agreements with possibly profligate or inexperienced male business partners. This is difficult to establish with any certainty in the absence of further evidence, but it remains an unexpected and interesting perspective on women and debt in later medieval England.

One woman who used staple credit fairly regularly in the early sixteenth century, and who therefore might act as an exemplar, was Beatrice Lavender. Beatrice Lavender was a London widow, which perhaps hints where some of the venture capital for her business came from. She does not seem to have transacted debts in partnership with her husband before he died, and nothing has yet been discovered about him. She extended credit at least four times on merchandise to Londoners and members of the gentry of Kent and Suffolk. The amounts she extended were of medium value, ranging between $£ 20$ and $£ 120$. These certificates, of course, represent only those debts that were not repaid to her, so it likely that she transacted many other deals with customers about which we remain ignorant. Her busiest year was 1517 in which she lent a total of $£ 120$ in three separate transactions 
in March, July, and September of that year. ${ }^{72}$ Two of her customers in that year were gentlemen from Kent and Suffolk and the third was a partnership of a brewer and a skinner of London. In one of these, for the largest amount $(£ 60)$ Beatrice extended the credit in partnership with a London merchant, Thomas Barnewe. ${ }^{73}$ It is conceivable that she used her capital and reputation to invest in Barnewe's trading venture. The way Beatrice's customers are described in the certificates allows some conjectural assessment to be made about her credit portfolio. It seems likely that the two gentlemen, John Grigby of Sevenoaks and Straumist Throkmerton of South Elmham (Southelmham), bought goods from Beatrice whilst in London - they lived relatively close to the capital - indeed she may have been a regular supplier of goods to these gentry households. One of the certificates specifically mentions, albeit in a formulaic way, that the credit was given 'for merchandise'. ${ }^{74}$ Her other two customers in that year were (probably) members of two of the London livery companies - the Brewers and the Skinners. These men, Stephen Laurence and John Hatton, would have, in reality, been wholesale merchants dealing in malt and other products, including imported hops for beer in this period (for brewing) and furs and skins (as a skinner). These men failed to repay what they owed to Beatrice and she sued them relatively quickly - leaving no more than two months after these debts had defaulted - through the Westminster staple court. The speed at which merchants sued their defaulting customers speaks to the commercial requirement to recover outstanding debts as quickly as possible in the vigorous market of the early sixteenth century. She is found two years later extending $£ 120$ in one transaction to another Kent partnership, one of whom, William Wyllard of Leigh, is described in the certificate as a yeoman. ${ }^{75}$ Finally, in 1523 Beatrice lent $£ 60$ to another London gentleman, Charles Kurvell, thereby returning once more to her familiar gentry customer base. ${ }^{76}$ Assuming she had been extending credit successfully between these defaulted transactions recorded in the certificates, then she had had a respectable mercantile career for at least six years. It was women like Beatrice Lavender who satisfied a part - albeit a small part - of the ample demand for trade finance in England in the later Middle Ages.

\footnotetext{
72 TNA C 131/102/8; C 152/65/2/83; C 152/65/2/15.

73 TNA C $152 / 65 / 2 / 83$.

74 TNA C $152 / 65 / 2 / 83$.

75 TNA C $152 / 65 / 2 / 199$.

76 TNA C 241/277/33.
} 


\section{Works Cited}

\section{Manuscripts and Archival Sources}

Deed Portfolios, Corporation of London Record Office, London, UK, CLA/007/EM/02/ I/004 and CLA/007/EM/04/002/259/291

Statute Merchant Roll of Coventry, Coventry Record Office, Coventry, UK, $\mathrm{BA} / \mathrm{E} / \mathrm{C} / 7 / 1-35$

Statute Staple Certificates, The National Archives, Kew, UK, C 131, C 241/, C152/65

\section{Primary Sources}

Borough Customs, ed. by Mary Bateson, Selden Society Publications, II (London: Quaritch, 1906)

'Inquisitions Post Mortem, Richard II, File 54', in Calendar of Inquisitions Post Mortem, Volume 16, Richard II, ed. by M. C. B. Dawes, M. R. Devine, H. E. Jones, and M. J. Post (London, 1974)

Lex Mercatoria and Legal Pluralism: A Late Thirteenth-Century Treatise and its Afterlife, ed. by M. B. Basile and others (Cambridge: Ames Foundation, 1998)

The Statute Merchant Roll of Coventry 1392-1416, ed. by A. Beardwood (Dugdale Society Publications, 17, 1939)

\section{Secondary Studies}

Barron, Caroline M., 'The “Golden Age” of Women in Medieval London', Reading Medieval Studies, 15 (1989), 35-58

,'Introduction: The Widow's World in Later Medieval London', in Medieval London Widows, 1300-1500, ed. by Caroline M. Barron and Anne F. Sutton (London: Hambledon Press, 1994), pp. xiii-xxxiv

Bennett, Judith M., Ale, Beer, and Brewsters in England: Women's Work in a Changing World, 1300-1600 (Oxford: Oxford University Press, 1996)

Bridbury, A. R., Economic Growth (London: Allen and Unwin, 1962)

Briggs, Chris, 'Empowered or Marginalized? Rural Women and Credit in Later Thirteenthand Fourteenth-Century England', Continuity and Change, 19 (2004), 13-43

Britnell, Richard, Britain and Ireland, 1050-1530 (Oxford: Oxford University Press, 2004)

- The Commercialisation of English Society, 1000-1500 (Manchester: Manchester University Press, 1994)

Brown, A. T., 'Surviving the Mid-Fifteenth-Century Recession: Durham Cathedral Priory, 1400-1520', Northern History, 47 (2010), 209-31

Childs, Wendy, “To oure losse and hindraunce”: English Credit to Alien Merchants in the Mid-Fifteenth Century', in Enterprise and Individuals in Fifteenth-Century England, ed. by Jennifer Kermode (Stroud: Alan Sutton, 1991), pp. 68-98 
Dyer, Christopher, Lords and Peasants in a Changing Society: The Estates of the Bishopric of Worcester, 680-1540 (Cambridge: Cambridge University Press, 1980)

Goddard, Richard, Credit and Trade in Later Medieval England, 1353-1532 (Basingstoke: Palgrave Macmillan, 2016)

Goldberg, P. J. P., Women, Work and Life-Cycle in a Medieval Economy: Women and Work in York and Yorkshire c. 1300-1520 (Oxford: Oxford University Press, 1992)

Hanawalt, B. A., 'Golden Ages for the History of Medieval English Women', in Women in Medieval History and Historiography, ed. by S. M. Stuard (Philadelphia: University of Pennsylvania Press, 1987), pp. 1-24

Hatcher, John, 'The Great Slump of the Mid-Fifteenth Century', in Progress and Problems in Medieval England, ed. by Richard Britnell and John Hatcher (Cambridge: Cambridge University Press, 1996), pp. 237-72

- Plague, Population and the English Economy, 1348-1530 (London: Macmillan, 1977)

Hatcher, John, A. J. Piper, and David Stone, 'Monastic Mortality: Durham Priory, 13951529', Economic History Review, 59 (2006), 667-87

Herlihy, D., Opera Muliebria: Women and Work in Medieval Europe (New York: Temple University Press, 1990)

Howell, M. C., Commerce Before Capitalism in Europe, 1300-1600 (Cambridge: Cambridge University Press, 2010)

Hutton, Shennan, 'Property, Family and Partnership: Married Women and Legal Capability in Late Medieval Ghent', in Married Women and the Law in Pre-Modern Northwest Europe, ed. by Cordelia Beattie and Matthew Frank Stevens (Woodbridge: Boydell and Brewer, 2013), pp. 155-72

- Women and Economic Activities in Late Medieval Ghent (Basingstoke: Palgrave MacMillan, 2011)

Kermode, Jennifer, Medieval Merchants: York, Beverley and Hull in the Later Middle Ages (Cambridge: Cambridge University Press, 1998)

—_, 'Merchants, Overseas Trade and Urban Decline: York Beverley and Hull c. 13801500', Northern History, 23 (1987), 51-73

— , 'Money and Credit in the Fifteenth Century: Some Lessons from Yorkshire', Business History Review, 54 (1991), 475-501

Kowaleski, M., 'Women's Work in a Market Town: Exeter in the Late Fourteenth Century', in Women and Work in Pre-Industrial Europe, ed. by B. A. Hanawalt (Bloomington: Indiana University Press, 1986), pp. 145-64

Lacey, K., 'Women and Work in Fourteenth and Fifteenth-Century London', in Women and Work in Pre-Industrial England, ed. by L. Charles and L. Duffin (London: Croom Helm, 1985), pp. 24-82

Muldrew, Craig, The Economy of Obligation: The Culture of Credit and Social Relations in Early Modern England (Basingstoke: Palgrave MacMillan, 1998)

Nightingale, Pamela, 'Monetary Contraction and Mercantile Credit in Later Medieval England', Economic History Review, 43 (1990), 560-75 
—-, 'Money and Credit in the Economy of Late Medieval England', in Medieval Money Matters, ed. by D. Wood (Oxford: Oxbow, 2004), pp. 51-71

O'Conner, S. J., 'Finance, Diplomacy and Politics: Royal Service by Two London Merchants in the Reign of Edward III', Historical Research, 67 (1994), 18-39

Phipps, Teresa, 'Gendered Justice? Women, Law and Community in Fourteenth-Century Nottingham', Transactions of the Thoroton Society, 118 (2014), 64-85

_ Century England' (unpublished doctoral thesis, University of Nottingham, 2015)

Postan, M., 'Credit in Medieval Trade', The Economic History Review, 1 (1928), 234-61

Stevens, Matthew Frank, 'London Women, the Courts and the "Golden Age”: A Quantitative Analysis of Female Litigants in the Fourteenth and Fifteenth Centuries', The London Journal, 37 (2012), 67-88

- 'London's Married Women and Coverture in the Court of Common Pleas', in Married Women and the Law in Pre-Modern Northwest Europe, ed. by Cordelia Beattie and Matthew Frank Stevens (Woodbridge: Boydell and Brewer, 2013), pp. 115-31

Wood, Diana, Medieval Economic Thought (Cambridge: Cambridge University Press, 2002) 
